\title{
The Selective mGlu5 Receptor Antagonist MTEP, Similar to NMDA Receptor Antagonists, Induces Social Isolation in Rats
}

\author{
Eliza Koros*,',3, Holger Rosenbrock', Gerald Birk', Carmen Weiss' and Frank Sams-Dodd ',4 \\ 'Department of CNS Research, Boehringer-Ingelheim Pharma GmbH \& Co. KG, Biberach, Germany; ' $G e n o m i c s$ Group, Boehringer-Ingelheim \\ Pharma GmbH \& Co. KG, Biberach, Germany; ${ }^{3}$ Department of Pharmacology and Physiology of the Nervous System, Institute of Psychiatry \\ and Neurology, Warsaw, Poland
}

\begin{abstract}
It has repeatedly been shown that uncompetitive $\mathrm{N}$-methyl-D-aspartate (NMDA) receptor antagonists can mimic certain aspects of positive and negative symptoms of schizophrenia in human volunteers and laboratory animals. The purpose of the present study was to expand these findings and to determine whether the selective metabotropic glutamate receptor subtype 5 (mGluR5) antagonist, MTEP (3-[(2-methyl- I,3-thiazol-4-yl)ethynyl]pyridine), could induce similar effects in Wistar rats. First, MTEP (I.0-10.0 mg/kg; intraperitoneally) after acute and subchronic (daily for 5 days) administration as well as the uncompetitive antagonists of the NMDA receptor of either high affinity, phencyclidine (0.5-4.0 mg/kg; subcutaneously (s.c.)) and (+)-MK-80I (0.03-0.25 mg/kg; s.c.), or low-moderate affinity, ketamine (2.0-16.0 mg/kg; s.c.) and memantine (0.15-20.0 mg/ $/ \mathrm{kg}$; s.c.), following daily administration for 3 days were tested in the social interaction test to determine their ability to reproduce the negative and positive symptoms measured by social isolation and stereotyped behavior, respectively. Second, the compounds were tested in the motility test following acute administration to determine their ability to induce locomotor hyperactivity reflecting the positive symptoms. In line with previous findings, all examined NMDA receptor antagonists produced social interaction deficits, locomotor hyperactivity, and stereotypy except memantine. Notably, this study found that MTEP following both acute and subchronic administration dose-dependently induced social isolation, but did not cause either locomotor hyperactivity or stereotypy. These data demonstrate that social behavior deficits in rats can be caused by both the blockade of the NMDA receptor and the inhibition of mGluR5, whereas mGluR5 antagonists may not independently be able to mimic the positive symptoms.

Neuropsychopharmacology (2007) 32, 562-576. doi:I0. I038/sj.npp. I 30 I I33; published online I4 June 2006
\end{abstract}

Keywords: MTEP; NMDA receptor antagonists; social behavior; negative symptoms; schizophrenia; rat

\section{INTRODUCTION}

In schizophrenia, social withdrawal together with poverty of speech, blunted affect, anhedonia, and avolition represent negative or deficit state symptoms referred to as a reduction in normal functioning (Andreasen et al, 1990). Compared with positive symptoms, for example, paranoia, delusions, and hallucinations, the negative symptoms tend to be more pervasive and persistent, more related to cognitive deficits, and much less sensitive to antipsychotic treatment (Fenton and McGlashan, 1991; Mueser and McGurk, 2004). The disturbances of social functioning were classified as a key

*Correspondence: Dr E Koros, Department of CNS Research, Boehringer-Ingelheim Pharma GmbH \& Co. KG, 65 Birkendorfer Strasse, D-88397 Biberach, Germany, Tel: + 49 735I 54 97876, Fax: + 49735 I 54 98928, E-mail: Eliza.Koros@bc.boehringer-ingelheim.com ${ }^{4}$ Current address: Bionomics Ltd Europe, Rue Jean Sapidus, Parc d'Innovation, F-67400 Illkirch, France

Received 28 November 2005; revised 26 April 2006; accepted I 5 May 2006

Online publication: 23 May 2006 at http://www.acnp.org/citations/ Npp052306050697/default.pdf item of the cluster of negative symptoms. The deficits in social activity are often present as early as in the premorbid and prodromal stage of schizophrenia as well as throughout the entire course of the illness, even during periods of remission (Goldberg and Schmidt, 2001; Häfner et al, 1999; Wiersma et al, 2000). Clinical observations with phencyclidine (PCP; ( $N$-(1-phenylcyclohexyl)piperidine) and ketamine (2-(2-chlorophenyl)-2-(methylamino)-cyclohexanone) show that reduced function of the $N$-methyl-D-aspartate (NMDA) receptor can mimic along with positive symptoms several aspects of negative symptoms, including social withdrawal, and cognitive deficits seen in schizophrenic patients (Adler et al, 1999; Javitt and Zukin, 1991; Krystal et al, 1994; Lahti et al, 2001). In line with clinical findings, preclinical studies have shown that different antagonists of the NMDA receptor, uncompetitive (ie, PCP, $(+)$-MK-801 $((+)$-5-methyl-10,11-dihydro-5H-dibenzo-[a,d]-cyclohepten5,10-imine), ketamine) and competitive (ie, $( \pm)$-CPP, (3(( \pm )-2-carboxypiperazine-4-yl)propyl-1-phosphonic acid)), along with hyperactivity and stereotyped behavior induce social isolation in laboratory animals (Corbett et al, 1995; Nagai et al, 2003; Rung et al, 2005a; Sams-Dodd, 1995, 
1996; Silvestre et al, 1997). Additional supportive evidence has come from behavioral experiments on mutant mice. It has been demonstrated that mice with reduced NMDA receptor expression avoided contacts with cage mates as well as with unfamiliar mice (Duncan et al, 2004; Mohn et al, 1999). Furthermore, atypical antipsychotic drugs, which are the most effective currently available medications in treating the negative symptoms in schizophrenic patients, have been shown to improve the social deficits displayed by either the NMDA receptor knockdown mice or NMDA receptor antagonist-treated animals (Becker and Grecksch, 2004; Mohn et al, 1999; Rung et al, 2005b; SamsDodd, 1996, 1997).

Hence, the NMDA receptor antagonist-induced social isolation in rats is widely used as an experimental model for the negative symptoms of schizophrenia with face and predictive validity (Becker and Grecksch, 2004; Ellenbroek and Cools, 2000; Rung et al, 2005a; Sams-Dodd, 1999).

Although direct inhibition of the NMDA receptor with antagonists acting at different regulatory sites within the receptor complex (for a review, see Kew and Kemp, 2005) is the most obvious approach to decrease glutamatergic neurotransmission, such effect can also be achieved via indirect modulation of this receptor (Marino and Conn, 2002). Recently, activation of the metabotropic glutamate receptor subtype 5 (mGluR5) has been shown to stimulate neuronal glutamate release in in vitro (Fazal et al, 2003; Thomas et al, 2000) and in vivo (Pintor et al, 2000) experimental models. It has also been found that mGluR5 can modulate the NMDA receptor function at the molecular and cellular level (Awad et al, 2000; Brakeman et al, 1997; Doherty et al, 1997). Further, the opposite direction of this modulation has been reported as well, thereby suggesting a reciprocal positive-feedback interaction between these two receptor subtypes (Alagarsamy et al, 1999, 2005; Luthi et al, 1994). Importantly, at the behavioral level, antagonists of the mGluR5 have been found to potentiate the effects of NMDA receptor antagonists in several tests including prepulse inhibition (PPI) of the startle response, locomotor activity, memory tasks, and unilateral 6-OHDA-lesion model (Henry et al, 2002; Homayoun et al, 2004; Kinney et al, 2002; Turle-Lorenzo et al, 2005). Moreover, mGluR5 antagonists have been shown to mimic some behavioral effects of NMDA receptor antagonists such as an impairment of working memory (Manahan-Vaughan and Braunewell, 2005; Homayoun et al, 2004), attenuation of the development of tolerance to morphine-induced antinociception (Kozela et al, 2003), as well as anxiolytic (Busse et al, 2004; Spooren et al, 2000), antiparkinsonian (Ossowska et al, 2001; Turle-Lorenzo et al, 2005), and antidepressant (Tatarczynska et al, 2001) actions. On the basis of the above considerations, we hypothesized that pharmacological inhibition of the mGlu5 receptor, similar to NMDA receptor blockade, might also evoke schizophrenialike symptoms.

Thus, the aim of the present study was to determine whether the selective mGlu5 receptor antagonist, MTEP (3-[(2-methyl-1,3-thiazol-4-yl)ethynyl]pyridine), can induce behaviors in animals resembling certain aspects of the negative and positive schizophrenia symptoms. For evaluating negative symptoms, measurement of social isolation in the social interaction test was used, and for positive symptoms, stereotypy in the social interaction test as well as hyperlocomotion in the motility test was assessed. MTEP as well as the high-affinity, PCP and (+)-MK-801, and the lowto moderate-affinity, ketamine and memantine (1-amino-3,5dimethyladamantane), uncompetitive NMDA receptor antagonists were examined in male Wistar rats in both tests.

\section{MATERIALS AND METHODS}

\section{Animals}

Male Wistar rats (Charles River, Germany) weighing 300$350 \mathrm{~g}$ at the time of testing were used in all experiments. The rats were housed in groups of three or four in Macrolon type III cages and kept in an animal room under standard laboratory conditions: $22 \pm 1^{\circ} \mathrm{C}, 55 \pm 5 \%$ of a relative humidity, and a 12-h light-dark cycle (light on 06001800). They had free access to water and standard rat chow throughout the entire study. The animals were acclimatized to the new environment for at least 2 weeks before being tested. All experiments were approved by the Ethical Committee of the regional council of Upper Swabia (Tübingen, Germany) and were performed in full accordance with the ethical standards laid down in the European Union guidelines (European Communities Council Directive 86/609/EEC).

\section{Drugs and Drug Administration}

PCP hydrochloride (Sigma-Aldrich Co., Saint Louis, USA), (+)-MK-801 maleate (Sigma-Aldrich Co., Saint Louis, USA), and memantine hydrochloride (Tocris, Ellisville, USA) were dissolved in sterile physiological saline $(0.9 \%$ $\mathrm{NaCl}$ ) and administered subcutaneously (s.c.) in a volume of $1 \mathrm{ml} / \mathrm{kg}$. Ketamine hydrochloride (WDT, Garbsen, Germany) was diluted with sterile physiological saline to obtain desired doses and was injected s.c. in a volume of $1 \mathrm{ml} / \mathrm{kg}$. MTEP (mol. wt. 200.3; synthesized at Boehringer Ingelheim Pharma KG, Biberach, Germany) was dissolved in $10 \%(\mathrm{v} / \mathrm{v})$ Tween 80 water and administered intraperitoneally (i.p.) in a volume of $2 \mathrm{ml} / \mathrm{kg}$. With the exception of MTEP, all doses were calculated as those of salts. Solutions of all drugs were prepared immediately before use.

\section{Experimental Procedures}

In the social interaction test, animals were randomly assigned to groups of three and were housed with the same cage mates during the entire experiment. All rats within a given cage received identical treatment and were never tested more than once. One week before testing, half of the rats within a treatment paradigm were dyed with black hair color on the rear part of the body. The rats received daily injections in their home cage for 3 days of a given compound or vehicle and were tested on the day of the last injection after the appropriate pretreatment time had expired. The 3-day treatment schedule for PCP and other uncompetitive NMDA receptor antagonists was selected based on studies showing that a tolerance to the ataxic effects of PCP, but not to the social behavior, rapidly develops after repeated administration (Sams-Dodd, 1996). MTEP was tested following either acute or subchronic 
administration (ie, daily for 5 days) in order to better determine the influence of ataxia and sedation on the behavioral response. All drugs were injected $45 \mathrm{~min}$ before the test except for MTEP and ketamine, which were given 60 and $30 \mathrm{~min}$ before testing, respectively. Pretreatment times were chosen based on previously published reports (Busse et al, 2004; Sams-Dodd, 2004; Silvestre et al, 1997) and our preliminary observation. Each treatment group included 6-12 pairs of rats per experiment.

In the motility test, animals were randomly assigned to groups of four and were housed with the same cage mates during the entire experiment. Each rat was tested only once. The rats received single injection of either given compound or vehicle on the day of testing. All drugs were administered after a $30 \mathrm{~min}$ adaptation period to the test conditions. Each treatment group included eight rats per experiment.

\section{Social Interaction Test}

The general design of the model was adapted from File (1980) and has previously been described in detail by SamsDodd (1995). Testing was conducted during the dark phase of the light-dark cycle in a dark arena to avoid any anxiogenic components and to favor high baseline levels of explorative behavior, and the rats were tested in an unfamiliar arena and with unfamiliar rat in order to reduce aggressive and territorial behaviors and to increase the level of social behavior (Sams-Dodd, 1996). Lighting in the experimental room consisted of a mixture of dimly illuminated red light and infrared LED-Arrays. The test was performed in an open arena (length, width, height: $150 \times 100 \times 40 \mathrm{~cm}$ ) with bedding of gray gravel (Dust-Free Cat-Litter). The gravel had been exposed to other rats before testing to provide a constant odor level in the arena. Above the arena, an analog monochrome camera with high red sensitivity (model DMK 3003-IR/C with H2Z 4516 CS-2, focal length $4.5-10.0 \mathrm{~mm} 1 / 2$ lens; The Imaging Source Europe Ltd, Bremen, Germany) was placed. The camera was connected to a DVD-video recorder (model DVDR 75/021; Philips, Hamburg, Germany) from which the video signal was fed into a Video-to-Fire Wire converter (model DFG/ 1394-1, The Imaging Source Europe Ltd, Bremen, Germany) connected to a PC. The behavior of the rats was analyzed online from the camera with an in-house application based on a commercially available machine vision software library (Halcon's Image Processing Software Library, MVTec Software Ltd, Munich, Germany). Data acquisition started automatically when the rats were placed into the arena and stopped after the preset 10 -min recording time. To obtain a movement pattern of each rat in the arena during the session, the positions of the rats were determined 12.5 times per second. The obtained coordinates were related to actual distances in the arena by an automatically determined conversion factor from pixel to meter. Additionally, all sessions were recorded on DVDs using the DVD recorder in order to create a backup database. Three arenas were run in parallel and were started at the same time.

The rats were placed in the experimental room the day before testing. On the day of testing, one dyed and one nondyed rat that had received identical treatment and were unfamiliar to each other were placed simultaneously into the unfamiliar arena $80-90 \mathrm{~cm}$ apart. The difference in body weight between the paired rats was within $15 \mathrm{~g}$. Their behavior was observed for $10 \mathrm{~min}$ and thereafter they were returned to the home cages.

Behavior of rats during the observation period were analyzed for the following parameters:

- Distance traveled $(\mathrm{cm})$. Total distance traveled during the 10-min observation period by each rat.

- Percent time in central zone (\%). Percentage of the 10min observation period spent in the central zone by each rat. The arena was divided into a central and a peripheral zone, which covered 33 and $66 \%$ of the arena, respectively.

- Social interaction (s). Duration of social behavior (ie, sniffing, crawling, following, or grooming the partner) defined as a maximal distance of $20 \mathrm{~cm}$ between the rats, that is, their centers of gravity.

Secondly, stereotypy behavior and ataxia were rated offline by a trained observer. Each recording on the DVDs was viewed for $1 \mathrm{~min}$ halfway through the 10 -min observation period, and each rat was given a separate score for PCP stereotyped behavior and ataxia. The score assigned for each behavioral measure was determined as the highest level of stereotypy or ataxia consistently observed during the rating period. The rating scales are given below and are after Castellani and Adams (1981).

- PCP stereotyped behavior: (0) stationary, little or no movement; (1) active, occasional to frequent movement; (2) active with episodes of repetitive forward head searching (the rat walked forward in a stereotyped manner along the periphery of the arena without engaging in other behaviors); (3) continuous forward head searching; (4) frequent repetitive rearing, side-toside weaving, or turning; (5) episodes of rapid jerky sideto-side, circular, or dorso-ventral head movements.

- Ataxia: (0) coordinated movements; (1) mild staggering, swaying locomotion, and rearing without falling; (2) moderate uncoordinated movements with occasional to frequent falling; (3) unable to support weight, crawling locomotion only; (4) no locomotion, lying on side or abdomen.

\section{Motility Test}

Testing was conducted during the light phase of the lightdark cycle in a brightly lit room to suppress the baseline activity level of control rats in order to increase the sensitivity of the test to drug-induced locomotor activity. Rats were placed individually into standard activity cages (length, width, height: $40.6 \times 40.6 \times 40.6 \mathrm{~cm}$ ) for a total of $150 \mathrm{~min}$. After $30 \mathrm{~min}$, when the animals were familiarized with the test environment, each rat was removed from the cage, injected with a given compound or vehicle, and immediately placed back into the cage. The distance traveled $(\mathrm{cm})$ and number of rearings were measured for 120 min post-injection. Eight rats (two subjects from each experimental group) were always tested simultaneously. Each activity cage (model E63-20; Coulbourn Instruments, Allentown, PA, USA) was equipped with two photobeam sensor rings (model E63-22; TruScan Photobeam Sensor, Coulbourn Instruments) positioned 4 and $12 \mathrm{~cm}$ above the 
cage floor. Interruptions of the photobeams, spaced $2.54 \mathrm{~cm}$ apart and providing a $1.27 \mathrm{~cm}$ spatial resolution, constituted rats' movements. The system measured the location of the animal in the $x$ and $y$ plane and along the $z$-axis twice per second. To separate the forward locomotion from stereotyped behavior, only movements that exceeded one full beam space were recorded. Sessions programming and data recording made use of the TruScan Photobeam Linc interface and the data acquisition TruScan 99 software package (Coulbourn Instruments) running on a PC compatible via the L18-16S/C Linc interface card (Coulbourn Instruments).

\section{Statistical Analysis}

Data analyses were conducted separately for each drug treatment and each behavioral parameter. The stereotypy and ataxia scores, which are of an ordinal type, were analyzed with Kruskal-Wallis one-way analysis of variance (ANOVA) on ranks followed, if significant, by a post hoc Dunn's test. Other data were analyzed by parametrical oneway ANOVA with Dunnett's post hoc test. The motility test measures, the distance traveled, and number of rearings
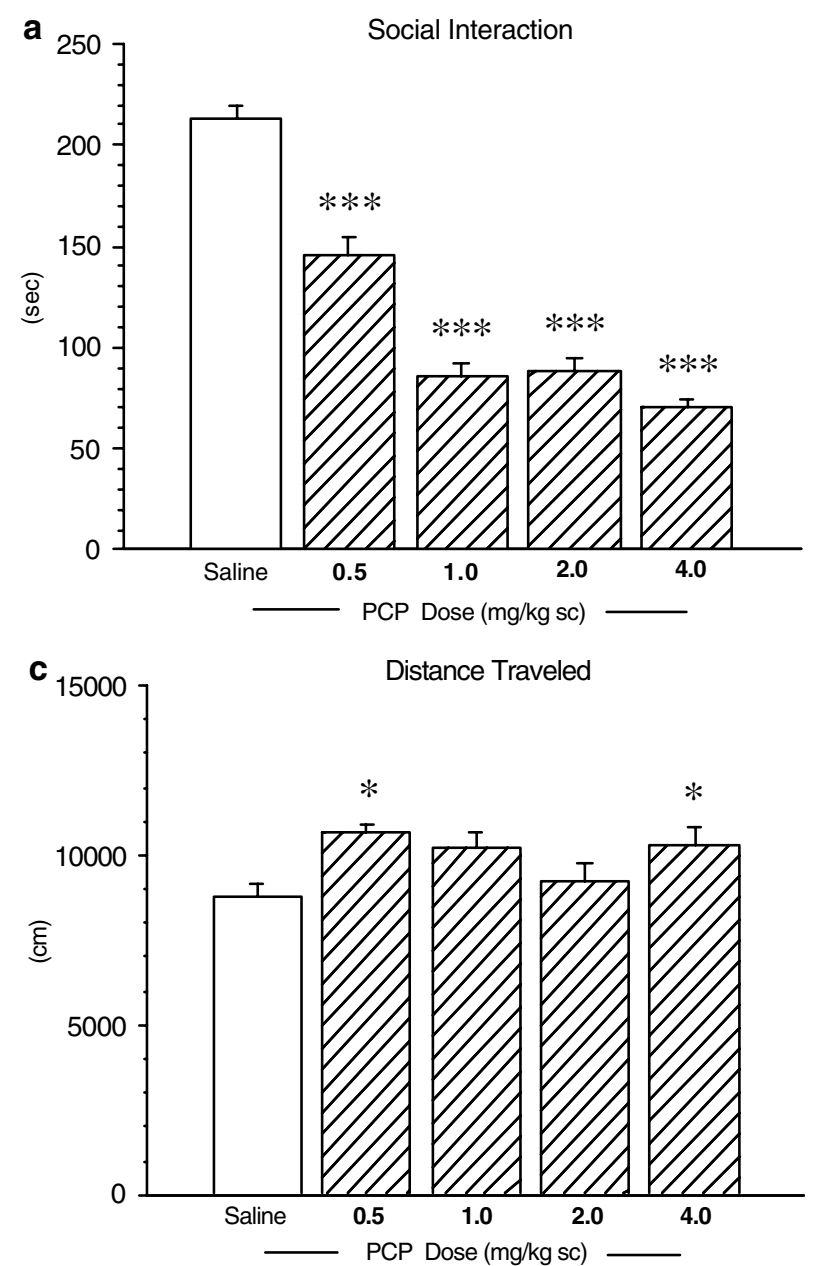

were log-transformed before statistical analysis. Post hoc tests were used to test for comparison with the control (saline- or vehicle-treated) group. A probability level of $p<0.05$ was regarded as significant. The stereotypy and ataxia scores are expressed as medians with interquartile ranges (25th-75th percentiles). Other data are presented as means with standard error of mean (SEM). The analyses were performed with the aid of the Sigma Stat software package for Windows version 2.03 (SPSS Inc., Chicago, IL, USA).

\section{RESULTS}

\section{PCP}

In the social interaction test, PCP $(0.5-4.0 \mathrm{mg} / \mathrm{kg} ; 1.8-$ $14.3 \mu \mathrm{mol} / \mathrm{kg}$ ), a high-affinity uncompetitive NMDA receptor antagonist, after treatment for 3 days showed significant effects on social interaction $\left(\mathrm{F}_{4,89}=80.53, p<0.001\right)$, percent time in central zone $\left(\mathrm{F}_{4,89}=14.27, p<0.001\right)$, distance traveled $\left(\mathrm{F}_{4,89}=3.67, p<0.01\right)$, stereotyped behavior $(H=67.23, p<0.001)$, and ataxia $(H=69.58, p<0.001)$ (Figure $1 \mathrm{a}-\mathrm{d})$. There was a significant reduction in social
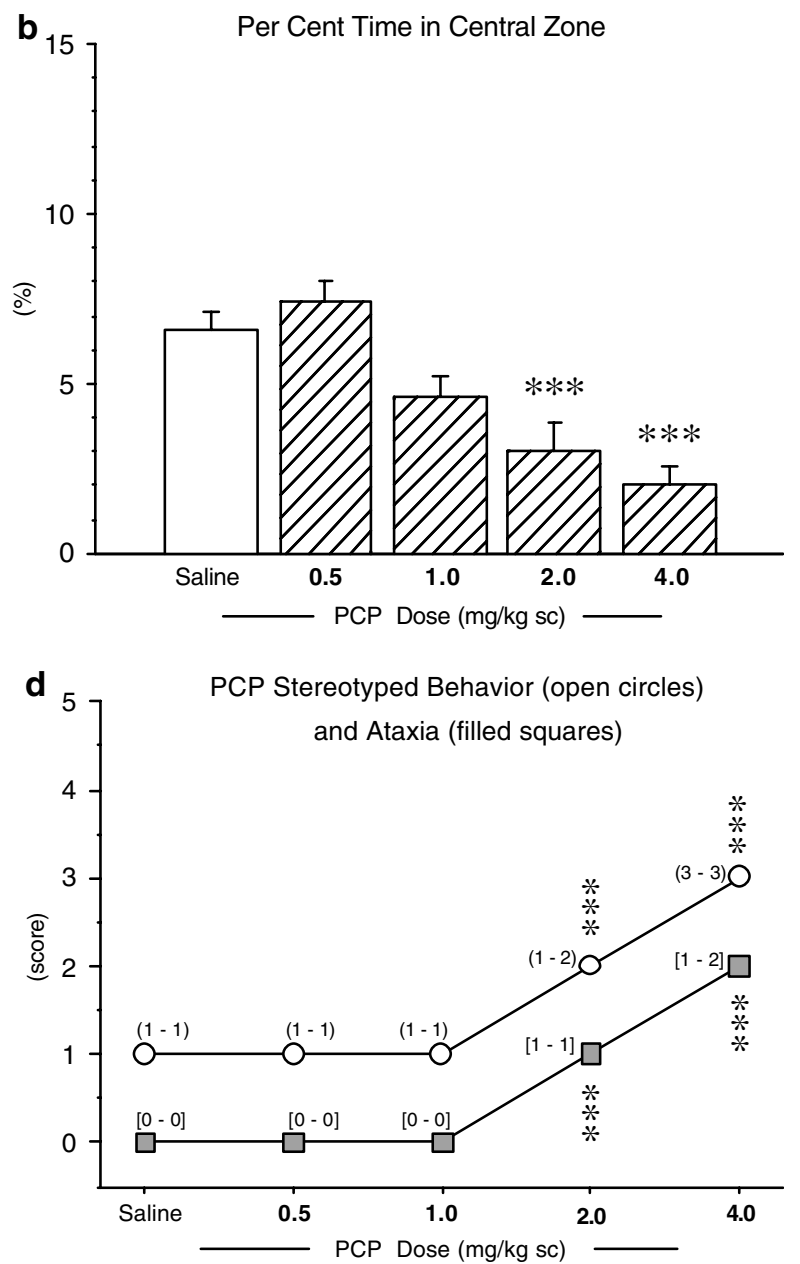

Figure I (a-d) Dose-response of PCP following daily administration for 3 days on the behavior of rats in the social interaction test. Data represent the mean + SEM, except stereotypy and ataxia scores shown as median with interquartile range. Interquartile ranges are shown in round and square brackets for stereotypy and ataxia, respectively. Each treatment group included nine pairs of rats. The pretreatment time was 45 min. $* p<0.05$; **** $p<0.00$ I significantly different from the saline group. 
interaction at all doses tested. At doses of 2.0 and $4.0 \mathrm{mg} / \mathrm{kg}$, percent time in central zone was significantly decreased, whereas stereotypy and ataxia scores were increased. For distance traveled, there was a significant increase at the lowest $(0.5 \mathrm{mg} / \mathrm{kg})$ and the highest $(4.0 \mathrm{mg} / \mathrm{kg})$ tested doses.

In the motility test, acute administration of PCP (0.5$4.0 \mathrm{mg} / \mathrm{kg})$ significantly affected both locomotor $\left(\mathrm{F}_{4,39}=\right.$ $36.38, p<0.001)$ and vertical activity $\left(\mathrm{F}_{4,39}=3.93, p<0.05\right)$. Distance traveled was increased across the dose range tested (Figure 7a), whereas the amount of rearings only at a dose of $0.5 \mathrm{mg} / \mathrm{kg}$ (Figure $8 \mathrm{a}$ ).

\section{( +)-MK-801}

In the social interaction test, $(+)-\mathrm{MK}-801(0.03-0.25 \mathrm{mg} / \mathrm{kg}$; $0.09-0.74 \mu \mathrm{mol} / \mathrm{kg}$ ), a high-affinity uncompetitive NMDA receptor antagonist, after treatment for 3 days showed significant effects on social interaction, percent in central zone, and distance traveled as well as on stereotyped behavior and ataxia $\left(\mathrm{F}_{4,59}=79.25, \mathrm{~F}_{4,59}=8.44, \mathrm{~F}_{4,59}=6.90\right.$, $H=51.33, H=51.51$, respectively; all $p$ 's $<0.001$; Figure 2a-d). ( + )-MK-801 significantly decreased social interaction with a concomitant increase in distance traveled and stereotypy scores at dosages of $0.06 \mathrm{mg} / \mathrm{kg}$ and upwards. At doses of 0.12 and $0.25 \mathrm{mg} / \mathrm{kg}$, (+)-MK-801 also elicited ataxia and reduced percent time spent in the central zone.

In the motility test, acute administration of $(+)$-MK$801(0.03-0.25 \mathrm{mg} / \mathrm{kg})$ increased both locomotor and vertical activity $\left(\mathrm{F}_{4,39}=83.56, \mathrm{~F}_{4,39}=4.05\right.$, respectively; all $p$ 's $<0.001)$. There was a significant increase in distance traveled at dosages of $0.06 \mathrm{mg} / \mathrm{kg}$ and upwards (Figure $7 \mathrm{~b}$ ). However, there was no significant difference in the amount of rearings between the saline group and (+)-MK-801 groups (Figure $8 \mathrm{~b}$ ).

\section{Ketamine}

In the social interaction test, ketamine $(2.0-16.0 \mathrm{mg} / \mathrm{kg} ; 7.3-$ $58.4 \mu \mathrm{mol} / \mathrm{kg}$ ), a low- to moderate-affinity uncompetitive NMDA receptor antagonist, after treatment for 3 days significantly decreased social interaction, percent time in central zone, and distance traveled, and also evoked stereo-
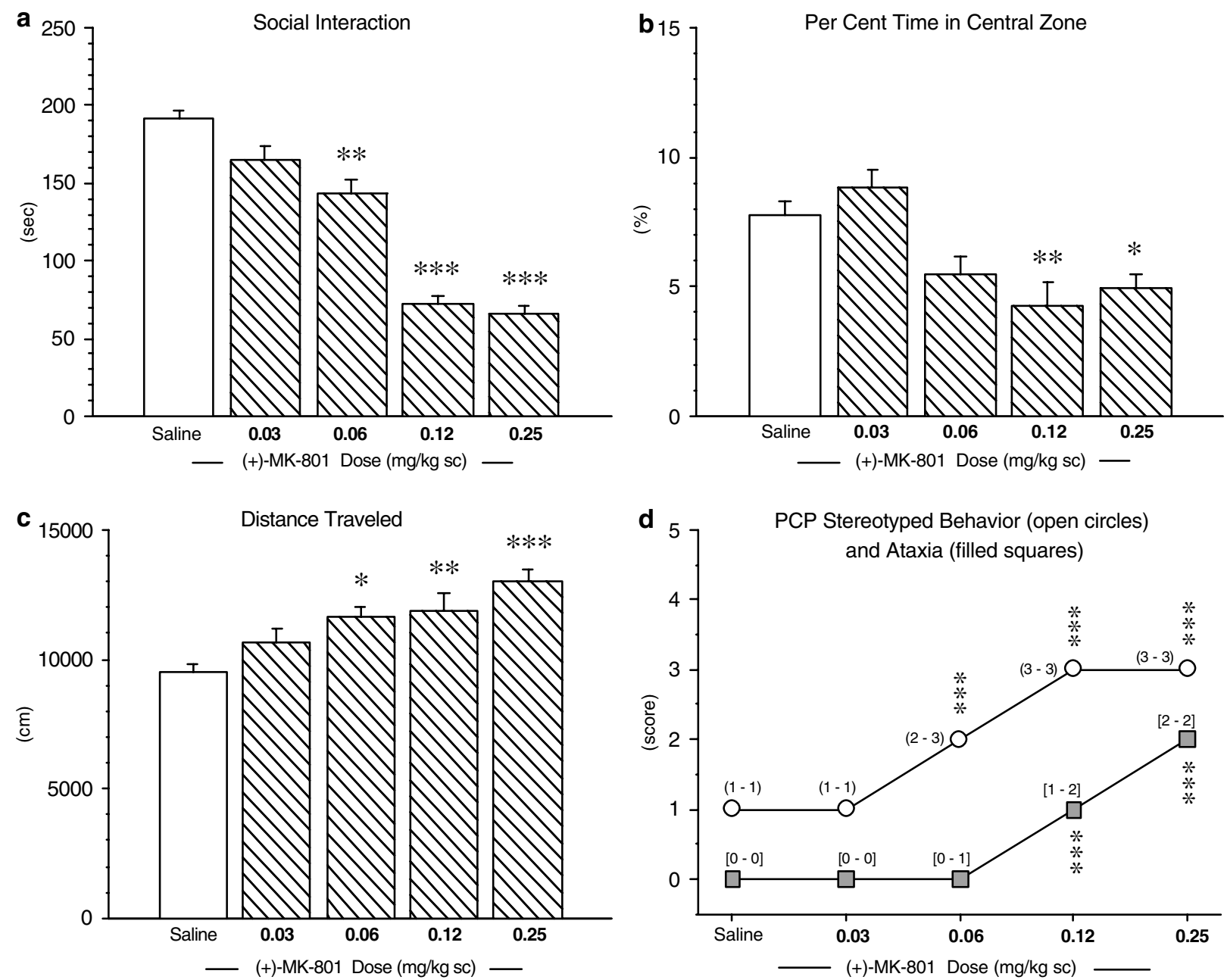

Figure 2 (a-d) Dose-response of (+)-MK-80I following daily administration for 3 days on the behavior of rats in the social interaction test. Data represent the mean + SEM, except stereotypy and ataxia scores shown as median with interquartile range. Interquartile ranges are shown in round and square brackets for stereotypy and ataxia, respectively. Each treatment group included six pairs of rats. The pretreatment time was 45 min. $* p<0.05$; ** $p<0.01 ; * * * * 0.00$ I significantly different from the saline group. 

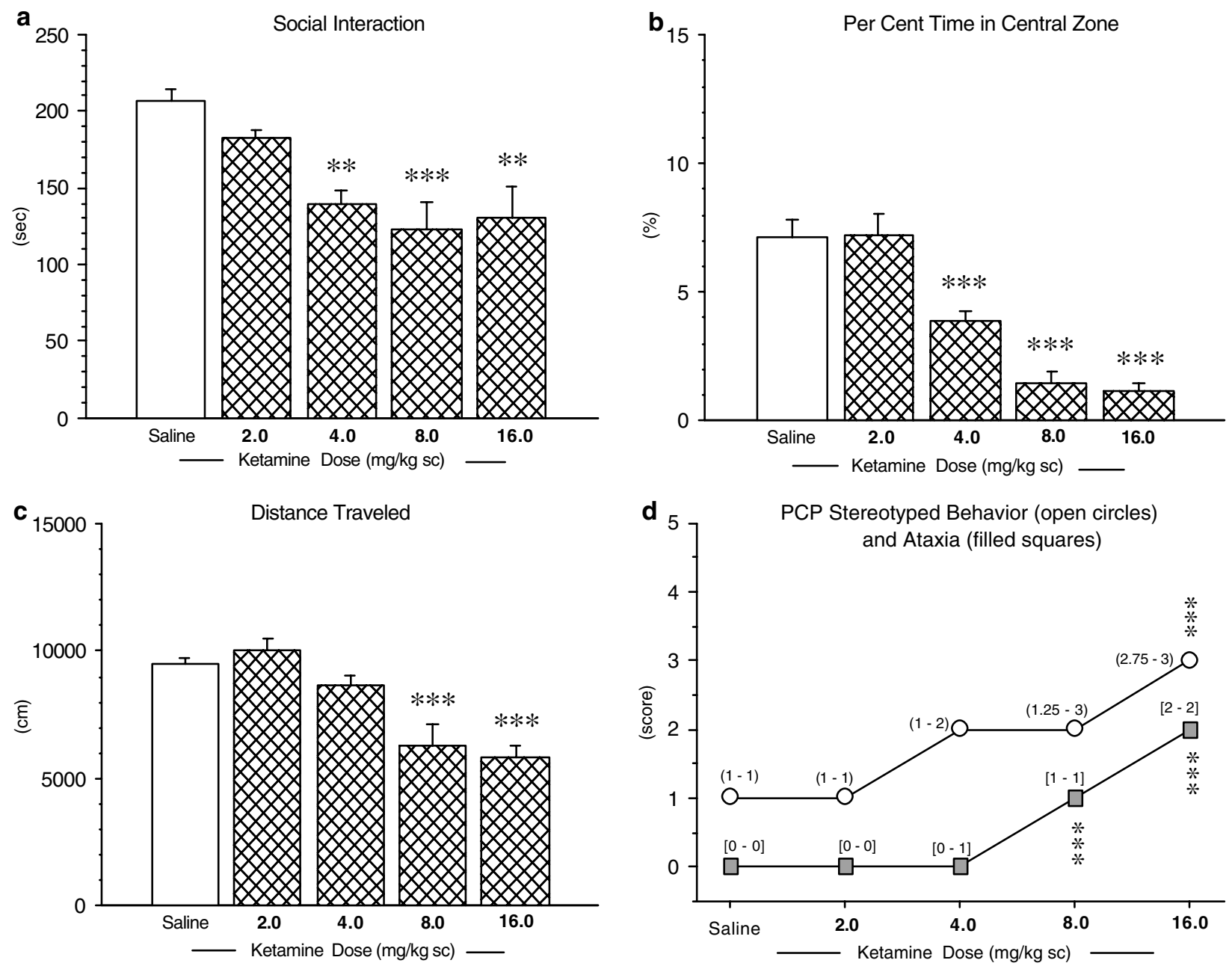

Figure 3 (a-d) Dose-response of ketamine following daily administration for 3 days on the behavior of rats in the social interaction test. Data represent the mean + SEM, except stereotypy and ataxia scores shown as median with interquartile range. Interquartile ranges are shown in round and square brackets for stereotypy and ataxia, respectively. Each treatment group included six pairs of rats. The pretreatment time was 30 min. $* * p<0.0$ l; **** $p<0.00$ I significantly different from the saline group.

typed behavior and ataxia $\left(\mathrm{F}_{4,59}=6.96, \mathrm{~F}_{4,59}=28.89, \mathrm{~F}_{4,59}=\right.$ $13.15, H=30.80, H=54.84$, respectively; all $p$ 's $<0.001$; Figure $3 a-d)$. There was a significant decrease in social interaction and percent time in central zone at doses of $4.0 \mathrm{mg} / \mathrm{kg}$ and upwards. Ketamine resulted in significantly decreased distance traveled and increased stereotyped behavior at doses of 8.0 and $16.0 \mathrm{mg} / \mathrm{kg}$, as well as in ataxia at a dose of $16.0 \mathrm{mg} / \mathrm{kg}$.

In the motility test, acute administration of ketamine $(2.0-16.0 \mathrm{mg} / \mathrm{kg})$ significantly affected both locomotor $\left(\mathrm{F}_{4,59}=8.41, p<0.001\right)$ and vertical activity $\left(\mathrm{F}_{4,59}=3.74\right.$, $p<0.05)$. Ketamine increased distance traveled at doses of 8.0 and $16.0 \mathrm{mg} / \mathrm{kg}$ (Figure 7c), and decreased the amount of rearings at a dose of $16.0 \mathrm{mg} / \mathrm{kg}$ (Figure $8 \mathrm{c}$ ).

\section{Memantine}

In the social interaction test, memantine $(1.25-20.0 \mathrm{mg} / \mathrm{kg}$; 5.8-92.7 $\mu \mathrm{mol} / \mathrm{kg}$ ), a low- to moderate-affinity uncompetitive NMDA receptor antagonist, after treatment for 3 days significantly decreased social interaction, percent time in central zone, distance traveled, and induced ataxia
$\left(\mathrm{F}_{5,119}=7.13, \quad \mathrm{~F}_{5,119}=15.10, \quad \mathrm{~F}_{5,119}=27.09, \quad H=69.28\right.$, respectively; all $p$ 's $<0.001)$, but not stereotyped behavior $(H=5.55, p=0.35)$ (Figure $4 \mathrm{a}-\mathrm{d})$. There was a significant decrease in social interaction seen at doses of $2.5 \mathrm{mg} / \mathrm{kg}$ and upwards, and in percent time in central zone and distance traveled at doses of $5.0 \mathrm{mg} / \mathrm{kg}$ and upwards. At doses of 10.0 and $20.0 \mathrm{mg} / \mathrm{kg}$, memantine additionally resulted in a slight, but significant, increase in ataxia. Memantine was also tested at lower doses $(0.15-0.62 \mathrm{mg} / \mathrm{kg} ; 0.7-2.9 \mu \mathrm{mol} / \mathrm{kg})$, but no significant effects were observed (data not shown).

In the motility test, acute administration of memantine $(2.5-20.0 \mathrm{mg} / \mathrm{kg} ; \quad 11.59-92.69 \mu \mathrm{mol} / \mathrm{kg})$ significantly increased locomotor activity $\left(\mathrm{F}_{4,39}=8.34, p<0.001\right)$, but did not induce any significant effects on vertical activity $\left(\mathrm{F}_{4,39}=0.71, p>0.5\right.$; Figure $\left.8 \mathrm{~d}\right)$. Memantine increased distance traveled at doses of 10.0 and $20.0 \mathrm{mg} / \mathrm{kg}$ (Figure 7d).

\section{MTEP}

In the social interaction test, acute administration of MTEP (1.0-10.0 mg/kg; $5.0-49.9 \mu \mathrm{mol} / \mathrm{kg}), \quad$ a noncompetitive 

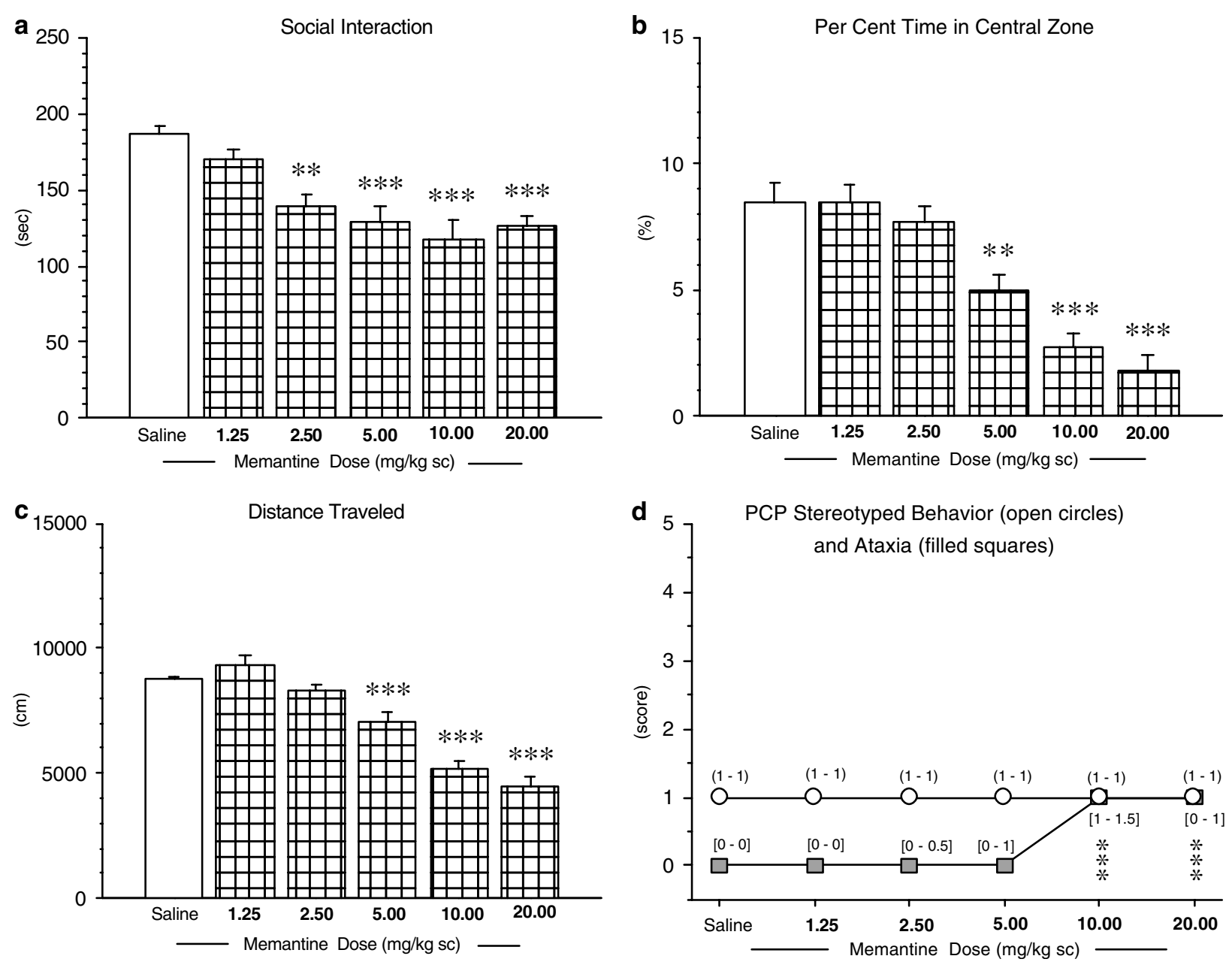

Figure 4 (a-d) Dose-response of memantine following daily administration for 3 days on the behavior of rats in the social interaction test. Data represent the mean + SEM, except stereotypy and ataxia scores shown as median with interquartile range. Interquartile ranges are shown in round and square brackets for stereotypy and ataxia, respectively. Each treatment group included 6-12 pairs of rats. The pretreatment time was 45 min. $* * p<0.01$; $* * * * 2<0.00$ I significantly different from the saline group.

mGluR5 antagonist, dose-dependently decreased social interaction, percent time in central zone, distance traveled, and stereotyped behavior $\left(\mathrm{F}_{3,95}=18.28, \quad \mathrm{~F}_{3,95}=15.02\right.$, $\mathrm{F}_{3,95}=57.29, H=52.78$, respectively; all $p$ 's $<0.001$ ), and showed a significant effect on ataxia $(H=21.50, p<0.001)$ (Figure 5a-d). Acute MTEP induced a significant decrease in social interaction and time in central zone at 3.0 and $10.0 \mathrm{mg} / \mathrm{kg}$ and in locomotor activity at all three doses. Additionally, sedation indicated by decreased stereotypy scores was seen at the highest dose tested of $10.0 \mathrm{mg} / \mathrm{kg}$. For ataxia, post hoc comparison revealed no significant difference compared with the vehicle group.

Similarly, subchronic administration of MTEP (1.0$10.0 \mathrm{mg} / \mathrm{kg}$ ) daily for 5 days showed dose-dependent decrease in social interaction, percent time in central zone, and distance traveled $\left(\mathrm{F}_{3,95}=18.68, \mathrm{~F}_{3,95}=34.26\right.$, $\mathrm{F}_{3,95}=11.42$, respectively; all $p$ 's $\left.<0.001\right)$, however showed no significant effects on either stereotyped behavior or ataxia $(H=11.93, H=6.20$, respectively; $p$ 's $>0.1)$ (Figure $6 a-d)$. Subchronic MTEP significantly decreased the level of social interaction, percent time spent in central zone at 3.0 and $10.0 \mathrm{mg} / \mathrm{kg}$, and locomotor activity at all three doses.
In the motility test, acute administration of MTEP (1.0 $10.0 \mathrm{mg} / \mathrm{kg}$ ) did not show any effects on locomotor activity $\left(\mathrm{F}_{3,46}=1.01, p>0.3\right.$; Figure $\left.7 \mathrm{e}\right)$, but significantly decreased vertical activity at all doses tested $\left(\mathrm{F}_{3,46}=18.30, p<0.001\right.$; Figure 8e).

\section{DISCUSSION}

The present study shows that the selective antagonist of the mGluR5, MTEP, can evoke changes in rat behavior that are considered to reflect social deficits of schizophrenia, but not positive symptoms. Specifically, MTEP induced social isolation, but did not cause either locomotor hyperactivity or stereotyped behaviors in rats. Although extrapolation of animal data to schizophrenia is problematic, the behavioral measures used in this study generally seem to be relevant to several aspects of clinical phenomenology (see Sams-Dodd, 2006 for a discussion on validation of animal models). As shown in Table 1, the distinct effects of $d$-amphetamine and the uncompetitive NMDA receptor antagonists on rats' social behavior in the social interaction test correspond well 

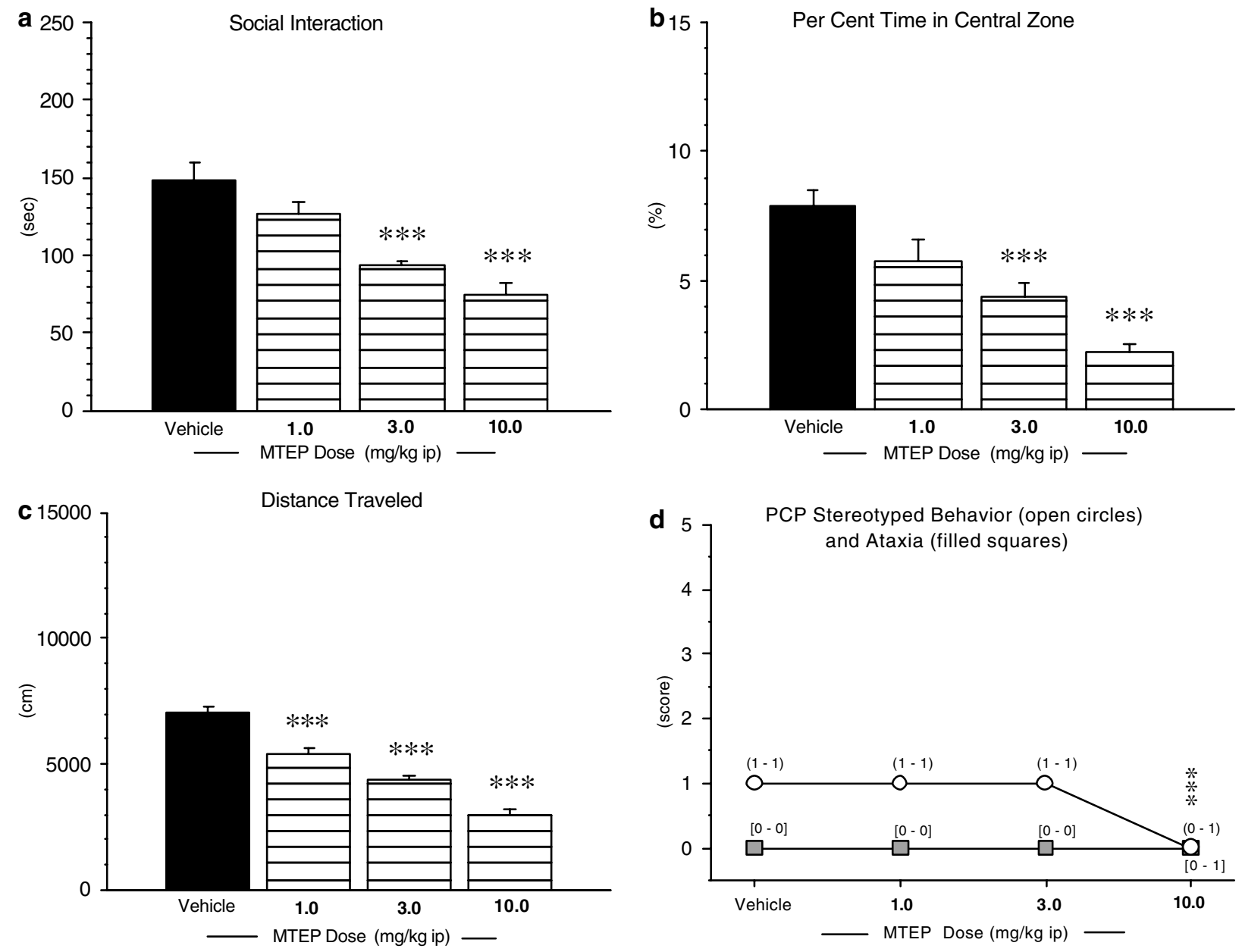

Figure 5 (a-d) Dose-response of MTEP following acute administration on the behavior of rats in the social interaction test. Data represent the mean + SEM, except stereotypy and ataxia scores shown as median with interquartile range. Interquartile ranges are shown in round and square brackets for stereotypy and ataxia, respectively. Each treatment group included 12 pairs of rats. The pretreatment time was 60 min. $* * * * 0<0.001$ significantly different from the vehicle group.

with clinical observations that the NMDA receptor antagonists, but not $d$-amphetamine, induce certain aspects of negative symptoms of schizophrenia. This suggests that social isolation in rats may be predictive of social deficits of negative schizophrenia symptoms. Comparison to the clinical findings also suggests that stereotyped behavior as well as locomotor hyperactivity in the motility test, but not locomotion in the social interaction test, corresponds to certain aspects of positive symptoms in humans. Similarly, locomotor hyperactivity in the motility test may be a useful indicator of psychotomimetic effects of a compound, as the compounds inducing psychosis in humans can also produce hyperactivity in rats (Table 1).

Another issue is the specificity of the obtained results in terms of confounding effects. In this study, all the examined compounds did produce social isolation in rats even at doses where the immobility (ie, a reduction in the score from one towards zero on the rating scale for stereotyped behavior) and ataxia were absent, suggesting their specific effects on social behavior. On the other hand, it could be suspected that the decreased levels of social interaction might have been indirectly caused by anxiogenic effects of the compounds, as all of them decreased exploration of the central zone of the arena. It seems, however, to be unlikely, as NMDA receptor antagonists have been found to possess rather anxiolytic than anxiogenic properties (Xie and Commissaris, 1992), and MTEP has been shown to display anxiolytic-like activity in a number of animal models of anxiety (Busse et al, 2004; Varty et al, 2005). There is rather a direct consequence of concomitantly present stereotyped behaviors manifested in walking in the periphery of an open field arena. Importantly, as reported by Sams-Dodd (1995), a hierarchical cluster analysis of the parameters simultaneously measured in the social interaction test detected no correlation between the level of social interaction, time spent in the central zone, and locomotor activity measured as the distance traveled.

In humans, adverse effects resembling schizophrenia-like symptoms following administration of various uncompetitive antagonists of NMDA receptors have been observed. It is very well known that PCP and ketamine can evoke an acute psychotic state, which incorporates positive as well as negative symptoms including social withdrawal in healthy volunteers (Krystal et al, 1994; Lahti et al, 2001; Luby et al, 1959; Morgan et al, 2004). There have also been reports on stereotyped head rolling in some individuals after PCP 

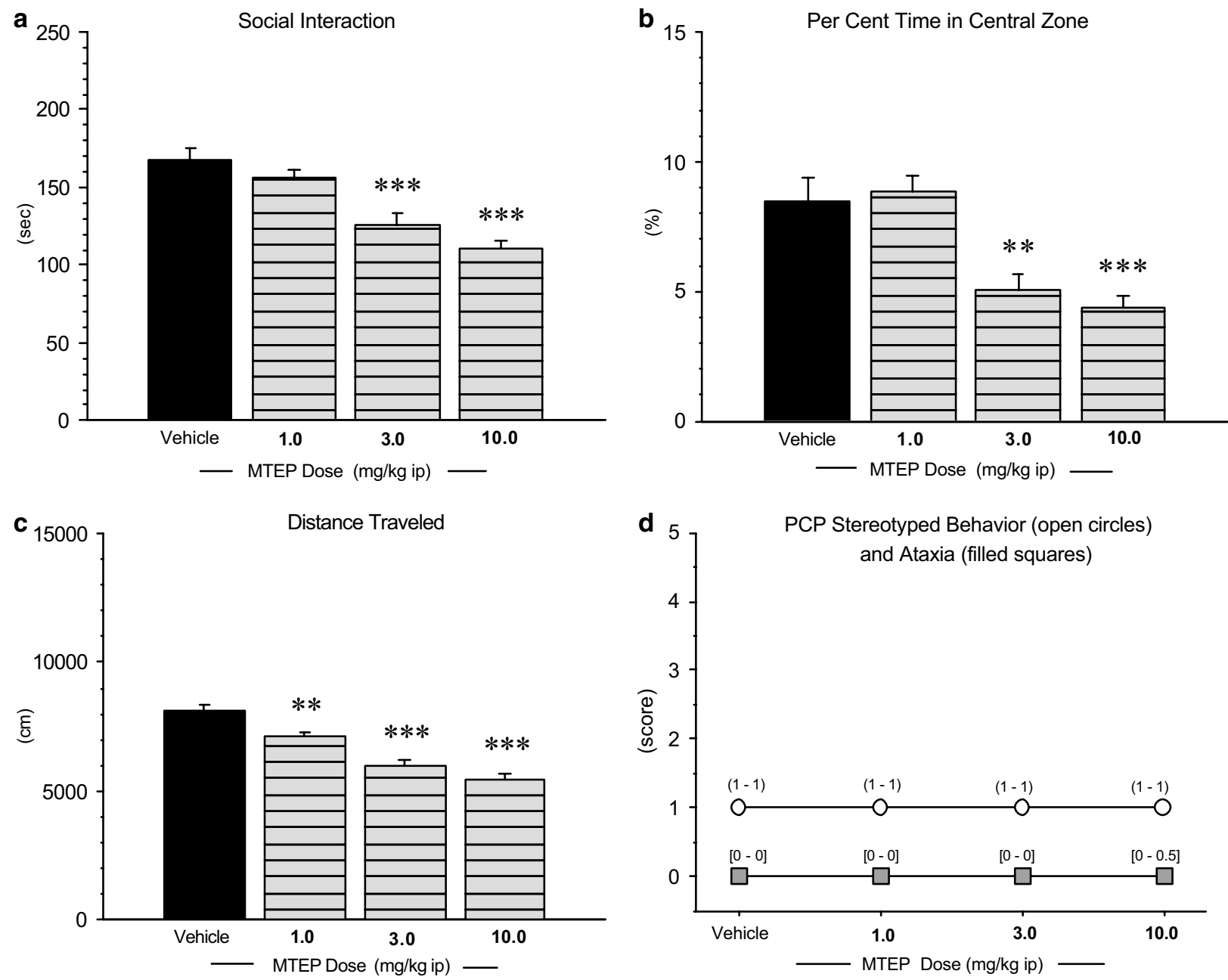

Figure 6 (a-d) Dose-response of MTEP following subchronic administration (daily for 5 days) on the behavior of rats in the social interaction test. Data represent the mean + SEM, except stereotypy and ataxia scores shown as median with interquartile range. Interquartile ranges are shown in round and square brackets for stereotypy and ataxia, respectively. Each treatment group included 12 pairs of rats. The pretreatment time was 60 min. $* * p<0.01$; **** $p<0.00$ I significantly different from the vehicle group.

(Burns and Lerner, 1976). In patients with schizophrenia, both compounds can precipitate psychotic episodes (Itil et al, 1967; Lahti et al, 2001; Malhotra et al, 1997). Also (+)-MK-801, which is not approved for human use, produced psychotomimetic effects in some patients during the clinical trial for the treatment of epilepsy (Leppik et al, 1988). Moreover, memantine, a clinically well-tolerated NMDA receptor antagonist used in the treatment of Alzheimer's dementia, has been reported to share with the aforementioned NMDA antagonists a number of unwanted effects including psychotomimetic effects, but usually they appear at doses higher than those of therapeutic relevance or a titration regime is used to avoid them (Fleischhacker et al, 1986; Rabey et al, 1992; Riederer et al, 1991).

Our results of the disruptive effects of PCP, (+)-MK-801, and ketamine on rats' social behavior in the social interaction test, when the experimental conditions are set at high baseline levels of explorative and social behaviors, are well in line with a number of previous findings (Becker et al, 2003; Corbett et al, 1995; Rung et al, 2005a; SamsDodd, 1996, 1998). In addition, we found that memantine could induce social withdrawal in the rat at dosages of
$2.5 \mathrm{mg} / \mathrm{kg}$ and upwards, but not at lower doses (data not shown). To the best of our knowledge, there is no other published report on social deficits produced by memantine. In contrast, there exist data showing that memantine does not affect or increase the time spent in social contacts during social encounters in mice (Sukhotina and Bespalov, 2000; Rodriguez-Arias et al, 2002). However, in these studies, the experimental conditions were set at low levels of spontaneous social behaviors, under which NMDA receptor antagonists have been documented to enhance social interaction (Dunn et al, 1989; McAllister, 1990). This perhaps surprising finding with memantine on social isolation should be put into the context. Social isolation together with previously and currently reported hyperactivity induced with memantine in the motility test clearly points to similarities between memantine and other uncompetitive NMDA receptor antagonists regarding their ability to induce the negative and positive symptoms of schizophrenia. In this respect, it is noteworthy that in laboratory animals, memantine, at relatively high doses, exhibited full substitution for (+)-MK-801 as well as for PCP in operant drug discrimination procedures (Grant et al, 

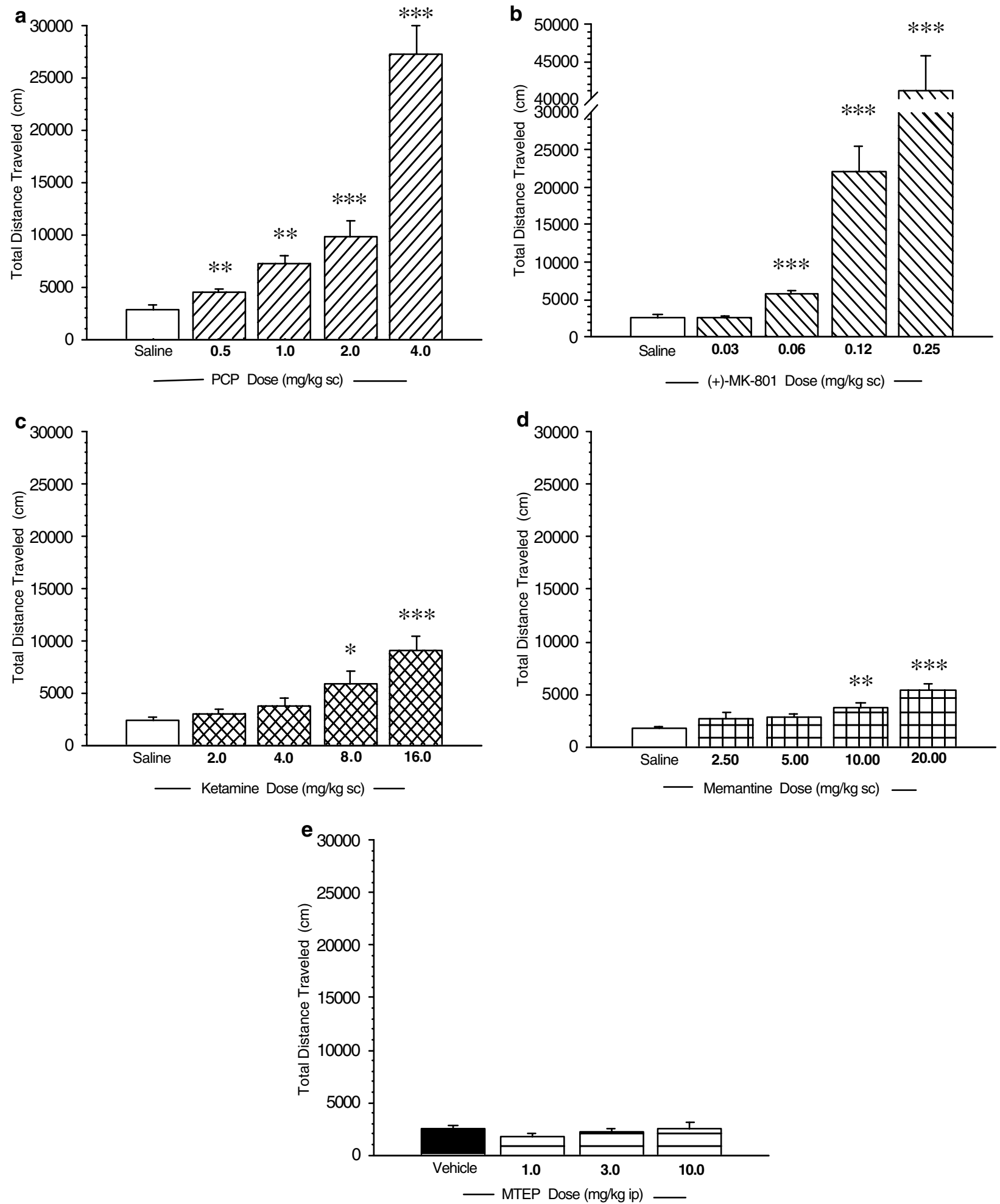

Figure 7 (a-e) Effects of acute administration of PCP (a), (+)-MK-80I (b), ketamine (c), memantine (d), and MTEP (e) on locomotor activity in rats in the motility test. Data represent the mean distance traveled per I 20 min +SEM. Numbers of rats in the groups varied from 8 to I2. *p $<0.05$; $* * p<0.0$ I; **** $p<0.00$ I significantly different from the respective control (saline- or vehicle-treated) group.

1996; Nicholson et al, 1998; Sanger et al, 1992). Together, these findings suggest that memantine and high-affinity NMDA receptor antagonists may produce common subjective effects and qualitatively similar adverse events in humans.
The observed reduction in social behavior following both acute and subchronic administration of MTEP was comparable to those produced by the uncompetitive NMDA receptor antagonists. MTEP, similar to the lowto moderate-affinity uncompetitive NMDA receptor antago- 

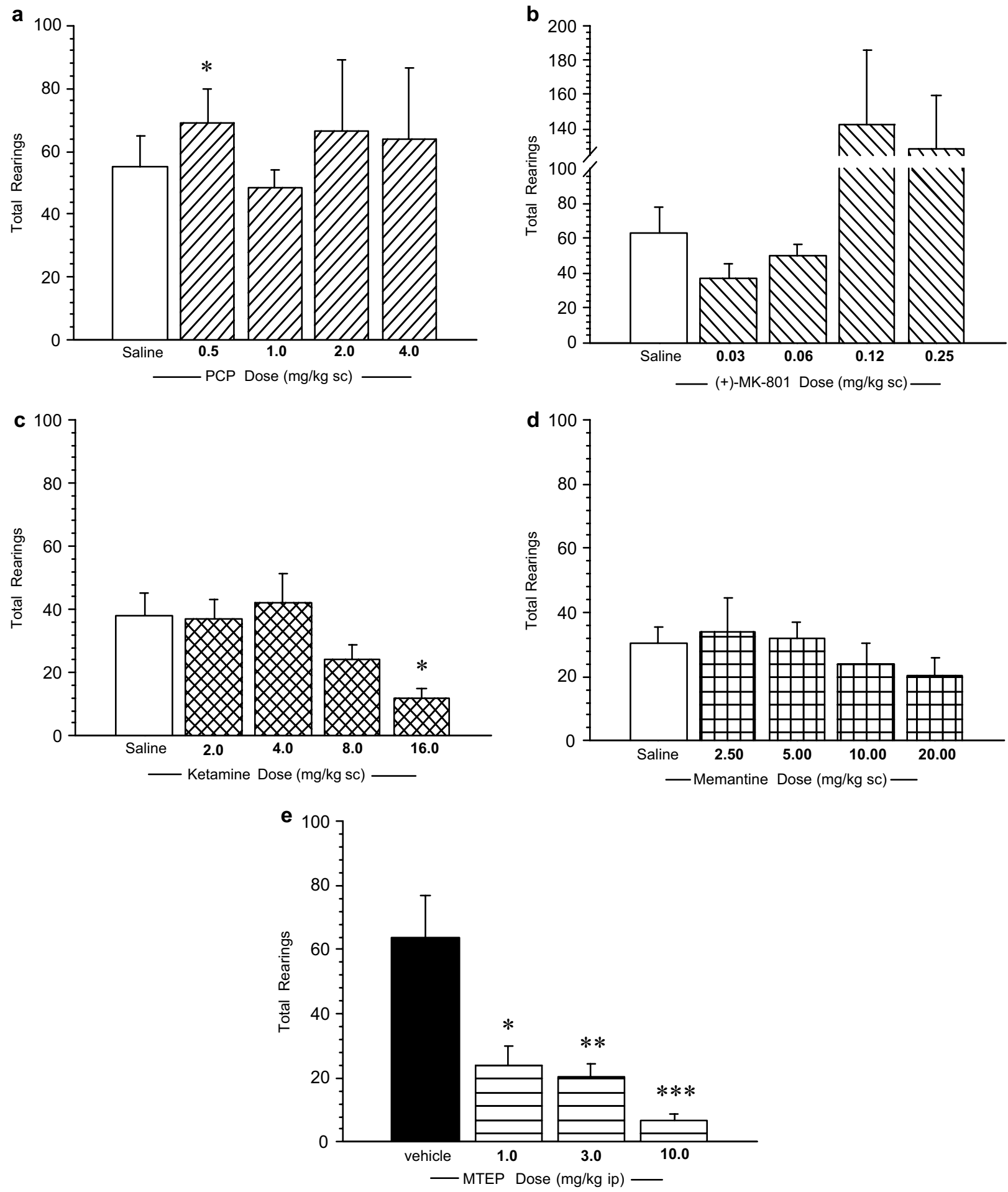

Figure 8 (a-e) Effects of acute administration of PCP (a), (+)-MK-80I (b), ketamine (c), memantine (d), and MTEP (e) on vertical activity in rats in the motility test. Data represent the mean number of rearings per $120 \mathrm{~min}+\mathrm{SEM}$. Numbers of rats in the groups varied from 8 to 12. *p $<0.05$; $* * p<0.01$; **** $p<0.00$ I significantly different from the respective control (saline- or vehicle-treated) group.

nists, decreased vertical activity of rats, but did not induce either locomotor hyperactivity or stereotyped behaviors unlike the examined NMDA receptor antagonists. In the light of these data, the pharmacological profile of MTEP seems to resemble that of uncompetitive NMDA receptor antagonists with respect to its effect on the negative symptoms, but lacks the ability to induce positive symptoms. A deleterious effect of MTEP on social behavior in rats raises a suspicion that, in human subjects, MTEP may induce undesirable side effects typical of uncompetitive NMDA receptor antagonists. However, MTEP has never been tested in man and its putative properties to evoke 
Table I Comparison of Effects of MTEP, Uncompetitive NMDA Receptor Antagonists, and d-Amphetamine in the Social Interaction and Motility Tests in Rats to Clinical Observations with these Compounds

\begin{tabular}{|c|c|c|c|c|c|c|c|}
\hline \multirow[b]{2}{*}{ Treatment } & \multicolumn{3}{|c|}{ Social interaction test } & \multirow{2}{*}{$\begin{array}{c}\text { Motility test } \\
\begin{array}{c}\text { Locomotor } \\
\text { activity }\end{array}\end{array}$} & \multicolumn{3}{|c|}{ Clinical observations } \\
\hline & $\begin{array}{c}\text { Social } \\
\text { behavior }\end{array}$ & $\begin{array}{l}\text { Locomotor } \\
\text { activity }\end{array}$ & $\begin{array}{c}\text { PCP stereotyped } \\
\text { behavior }\end{array}$ & & $\begin{array}{c}\text { Psychotomimetic } \\
\text { effects }\end{array}$ & $\begin{array}{l}\text { Positive } \\
\text { symptoms }\end{array}$ & $\begin{array}{l}\text { Negative } \\
\text { symptoms }\end{array}$ \\
\hline PCP & $\downarrow$ & $=$ & $\uparrow$ & $\uparrow$ & $+^{\mathrm{a}}$ & $+^{\mathrm{a}}$ & $+^{\mathrm{b}}$ \\
\hline$(+)-M K-80 I$ & $\downarrow$ & $\uparrow$ & $\uparrow$ & $\uparrow$ & $+^{c}$ & ND & ND \\
\hline Ketamine & $\downarrow$ & $\downarrow$ & $\uparrow$ & $\uparrow$ & $+^{d}$ & $+^{\mathrm{d}}$ & $+^{d}$ \\
\hline MTEP acute & $\downarrow$ & $\downarrow$ & $\downarrow$ & $=$ & ND & ND & ND \\
\hline MTEP subchronic & $\downarrow$ & $\downarrow$ & $=$ & ND & ND & ND & ND \\
\hline d-Amphetamine & $={ }^{f}$ & $={ }^{f}$ & $\uparrow^{f}$ & $\uparrow^{f}$ & +8 & +8 & - \\
\hline
\end{tabular}

$\uparrow$, increase; $\downarrow$, decrease; $=$, no change; - ineffective; + , effective; ND, not determined.

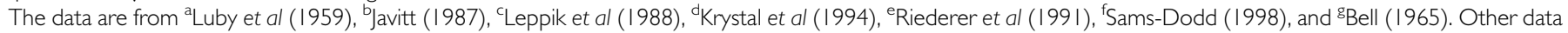
are based on Figures I-8.

schizophrenia-like symptoms can be only indirectly implied from animal studies. Notably, fenobam, a clinically validated anxiolytic agent with recently described noncompetitive mGluR5 antagonism and the structure belonging to a chemical class different from MTEP (Porter et al, 2005), has been reported to produce psychostimulant side effects in some patients with anxiety (Friedmann et al, 1980; Itil et al, 1978; Pecknold et al, 1982). This observation suggests that mGluR5 antagonism, similar to the NMDA receptor blockade, may have a psychotomimetic potential, at least in certain susceptible individuals. On the other hand, the lack of hyperactivity and stereotyped behavior after MTEP despite its deleterious effect on social interactions found in the present study is noteworthy. The present findings showing that MTEP did not enhance locomotor activity of rats are consistent with previous reports (Pietraszek et al, 2005; Varty et al, 2005), and may be attributed to the lack of ability of MTEP to activate the dopaminergic system. Interestingly, in line with the lack of stimulant effects of MTEP, there is the observation that MTEP and another mGluR5 antagonist, MPEP, unlike the uncompetitive NMDA receptor antagonists, do not disrupt PPI of acoustic startle, which is used as an animal model of sensorimotor gating deficits in schizophrenia. Both mGluR5 antagonists, however, have been found to potentiate disruption of PPI and locomotor activity induced by PCP or (+)-MK-801 in rats (Henry et al, 2002; Pietraszek et al, 2005). Thus, the profile of MTEP as well as MPEP on locomotor activity and PPI is different from that of the uncompetitive NMDA receptor antagonists. In contrast to the latter compounds, MTEP and by extension mGluR5 antagonists might be devoid of the propensity to evoke psychotomimetic effects in healthy humans. On the other hand, it seems that mGluR5 antagonism might potentiate psychotic symptoms in certain vulnerable populations. Studies with a broader range of mGluR5 antagonists will be essential to further characterize the mGlu5 receptor in this issue.

The mechanism(s) underlying the MTEP-induced deficits in social behavior remains to be determined, but it may be mediated via indirectly decreased function of the NMDA receptor. Experimental data indicate functional interaction between the NMDA and mGlu5 receptors. In particular, mGluR5 antagonists, at doses with no effect on their own, have been shown to potentiate the effects of NMDA receptor antagonists in different behavioral tests. And at high doses, these antagonists mimicked some behavioral effects of NMDA receptor antagonists (see Introduction). It has also been demonstrated that activation of mGluR5 potentiated NMDA receptor currents in the hippocampus (Doherty et al, 1997) and subthalamic nucleus (Awad et al, 2000). There are two most often pointed out intracellular mechanisms by which mGluR5 can potentiate NMDA receptors: the first one is an increase in intracellular $\mathrm{Ca}^{2+}$ concentration and activation of protein kinase $\mathrm{C}$ (PKC) (Benquet et al, 2002; Conn and Pin, 1997); and the second one is coupling to Homer proteins, which traffic mGlu5 receptors into and out of synapses (Ango et al, 2001; Brakeman et al, 1997; de Bartolomeis and Iasevoli, 2003).

Interestingly, NMDA receptor activation has been found to potentiate mGluR5-mediated responses (Alagarsamy et al, 1999). There are data showing that activation of NMDA receptors may lead to activation of calcineurin that in turn may modulate mGluR5 function by dephosphorylating mGluR5 at sites that are phosphorylated by PKC on the C-terminal tail of the receptor (Alagarsamy et al, 2005; Gereau and Heinemann, 1998). Moreover, it has been reported that a single administration of PCP in rats resulted in a decrease in the mGluR5 mRNA expression in the hippocampal formation and in a number of subcortical regions (Abe et al, 2001). By extension, this might suggest that the mGlu5 receptor may also contribute to the behavioral effects of PCP, including social isolation. However, this speculative assumption warrants further studies.

In summary, our findings indicate that the inhibition of mGluR5 by MTEP results in social behavior deficits in rats similar to those produced by the uncompetitive NMDA receptor antagonists, which in turn are believed to resemble 
social deficits observed in schizophrenic patients. Interestingly, MTEP did not produce locomotor hyperactivity and stereotyped behavior in rats, which are typically induced by the uncompetitive NMDA receptor antagonists, and are considered to reflect the positive symptoms of schizophrenia. Overall, these results suggest that clinical use of MTEP, similar to uncompetitive NMDA receptor antagonists, may be accompanied by adverse effects resembling certain schizophrenia-like symptoms. And therapeutic utility of mGluR5 antagonists has to be regarded with some degree of caution owing to a possibility of the highly undesirable side effects, at least in some patients. It remains to be determined if MTEP-induced social withdrawal can account for the inhibition of mGluR5 alone or for a synergistic interaction between the mGlu5 and NMDA receptors.

\section{REFERENCES}

Abe S, Suzuki T, Ito T, Yamaguchi M, Baba A, Hori T et al (2001). Effects of single and repeated phencyclidine administration on the expression of metabotropic glutamate receptor subtype mRNA in rat brain. Neuropsychopharmacology 25: 173-184.

Adler CM, Malhotra AK, Elman I, Goldberg T, Egan M, Pickar D et al (1999). Comparison of ketamine-induced thought disorder in healthy volunteers and thought disorder in schizophrenia. Am J Psychiat 156: 1646-1649.

Alagarsamy S, Marino MJ, Rouse ST, Gereau IV, Heinemann SF, Conn PJ (1999). Activation of NMDA receptors reverses desensitization of mGluR5 in native and recombinant systems. Nat Neurosci 2: 234-240.

Alagarsamy S, Saugstad J, Warren L, Mansuy IM, Gereau RW, Conn PJ (2005). NMDA-induced potentiation of mGluR5 is mediated by activation of protein phosphatase $2 \mathrm{~B} /$ calcineurin. Neuropharmacology 49: 135-145.

Andreasen NC, Flaum M, Swayze VW, Tyrrell G, Arndt S (1990). Positive and negative symptoms in schizophrenia. A critical reappraisal. Arch Gen Psychiat 47: 615-621.

Ango F, Prezeau L, Muller T, Tu JC, Xiao B, Worley PF et al (2001). Agonist-independent activation of metabotropic glutamate receptors by the intracellular protein Homer. Nature 411: 962-965.

Awad H, Hubert GW, Smith Y, Levely AI, Conn PJ (2000). Activation of metabotropic glutamate receptor 5 has direct excitatory effects and potentiates NMDA receptor currents in neurons of the subthalamic nucleus. J Neurosci 20: 78717879.

Becker A, Grecksch G (2004). Ketamine-induced changes in rat behaviour: a possible animal model of schizophrenia. Test of predictive validity. Prog Neuropsychopharmacol Biol Psychiat 28: 1267-1277.

Becker A, Peters B, Schroeder H, Mann T, Huether G, Grecksch G (2003). Ketamine-induced changes in rat behaviour: a possible animal model of schizophrenia. Prog Neuropsychopharmacol Biol Psychiat 27: 687-700.

Bell DS (1965). Comparison of amphetamine psychosis and schizophrenia. Br J Psychiat 111: 701-707.

Benquet P, Gee CE, Gerber U (2002). Two distinct signaling pathways upregulate NMDA receptor responses via two distinct metabotropic glutamate receptor subtypes. J Neurosci 22: 96799686.

Brakeman PR, Lanahan AA, O'Brien R, Roche K, Barnes CA, Huganir RL et al (1997). Homer: a protein that selectively binds metabotropic glutamate receptors. Nature 386: 284-288.

Burns RS, Lerner SE (1976). Perspectives: acute phencyclidine intoxication. Clin Toxicol 9: 477-501.
Busse CS, Brodkin J, Tattersall D, Anderson JJ, Warren N, Tehrani $\mathrm{L}$ et al (2004). The behavioral profile of the potent and selective mGlu5 receptor antagonist 3-[(2-methyl-1,3-thiazol-4-yl)ethynyl]pyridine (MTEP) in rodent models of anxiety. Neuropsychopharmacology 29: 1971-1979.

Castellani S, Adams PM (1981). Acute and chronic phencyclidine effects on locomotor activity, stereotypy and ataxia in rats. Eur $J$ Pharmacol 73: 143-154.

Conn JP, Pin JP (1997). Pharmacology and functions of metabotropic glutamate receptors. Annu Rev Pharmacol Toxicol 37: 205-237.

Corbett R, Camacho F, Woods AT, Kerman LL, Fishkin RJ, Brooks $\mathrm{K}$ et al (1995). Antipsychotic agents antagonize non-competitive $\mathrm{N}$-methyl-D-aspartate antagonist-induced behaviors. Psychopharmacology 120: 67-74.

de Bartolomeis A, Iasevoli F (2003). The Homer family and signal transduction system at glutamatergic postsynaptic density: potential role in behavior and pharmacotherapy. Psychopharmacol Bull 37: 51-83.

Doherty AJ, Palmer MJ, Henley JM, Collingridge GL, Jane DE (1997). (RS)-2-chloro-5-hydroxyphenylglycine (CHPG) activates mGlu5, but not mGlu1, receptors expressed in $\mathrm{CHO}$ cells and potentiates NMDA responses in the hippocampus. Neuropharmacology 36: 265-267.

Duncan GE, Moy SS, Perez A, Eddy DM, Zinzow WM, Lieberman JA et al (2004). Deficits in sensorimotor gating and tests of social behavior in a genetic model of reduced NMDA receptor function. Behav Brain Res 153: 507-519.

Dunn RW, Corbett R, Fielding S (1989). Effects of 5-HT1A receptor agonists and NMDA receptor antagonists in the social interaction test and the elevated plus maze. Eur J Pharmacol 169: 1-10.

Ellenbroek BA, Cools AR (2000). Animal models for the negative symptoms of schizophrenia. Behav Pharmacol 11: 223-233.

Fazal A, Parker F, Palmer AM, Croucher MJ (2003). Characterisation of the actions of group I metabotropic glutamate receptor subtype selective ligands on excitatory amino acids release and sodium-dependent re-uptake in rat cerebrocortical minislices. J Neurochem 86: 1346-1358.

Fenton WS, McGlashan TH (1991). Natural history of schizophrenia subtypes: II positive and negative symptoms and long term course. Arch Gen Psychiat 48: 978-986.

File SE (1980). The use of social interaction as a method for detecting anxiolytic activity of chlordiazepoxide-like drugs. J Neurosci Methods 2: 219-238.

Fleischhacker WW, Buchgeher A, Schubert H (1986). Memantine in the treatment of senile dementia of the Alzheimer type. Prog Neuropsychopharmacol Biol Psychiat 10: 87-93.

Friedmann CTH, Davis LJ, Ciccone PE, Rubin RT (1980). Phase II double blind controlled study of a new anxiolytic, fenobam (McN-3377) vs placebo. Curr Ther Res 27: 144-151.

Gereau RW, Heinemann SF (1998). Role of protein kinase C phosphorylation in rapid desensitization of metabotropic glutamate receptor 5. Neuron 20: 143-151.

Goldberg JO, Schmidt LA (2001). Shyness, sociability, and social dysfunction in schizophrenia. Schizophr Res 48: 343-349.

Grant KA, Colombo G, Grant J, Rogawski MA (1996). Dizocilpinelike discriminative stimulus effects of low-affinity uncompetitive NMDA antagonists. Neuropharmacology 35: 1709-1719.

Häfner H, Löffler W, Maurer K, Hambrecht M, an der Heiden W (1999). Depression, negative symptoms, social stagnation and social decline in the early course of schizophrenia. Acta Psychiatr Scand 100: 105-118.

Henry SA, Lehmann-Masten V, Gasparini F, Geyer MA, Markou A (2002). The mGluR5 antagonist MPEP, but not the mGluR2/3 agonist LY314582, augments PCP effects on prepulse inhibition and locomotor activity. Neuropharmacology 43: 1199-1209.

Homayoun H, Stefani MR, Adams BW, Tamagan GD, Moghaddam B (2004). Functional interaction between NMDA and mGlu5 
receptors: effects on working memory, instrumental learning, motor behaviors, and dopamine release. Neuropsychopharmacology 29: 1259-1269.

Itil TM, Keskiner A, Kiremitci N, Holden JM (1967). Effect of phencyclidine in chronic schizophrenia. Can Psychiatr Assoc J 12: $209-212$.

Itil TM, Seaman BA, Hugue M, Mukhopadhyay S, Blasucci D, Nq $\mathrm{KT}$ et al (1978). The clinical and quantitative EEG effects and plasma levels of fenobam $(\mathrm{McN}-3377)$ in subjects with anxiety: an open rising dose tolerance and efficacy study. Curr Ther Res 24: $708-724$

Javitt DC (1987). Negative schizophrenic symptomatology and the PCP (phencyclidine) model of schizophrenia. Hillside J Clin Psychiat 9: 12-35.

Javitt DC, Zukin SR (1991). Recent advances in the phencyclidine model of schizophrenia. Am J Psychiat 148: 1301-1308.

Kew JNC, Kemp JA (2005). Ionotropic and metabotropic glutamate receptor structure and pharmacology. Psychopharmacology 179: 4-29.

Kinney GG, Wittmann M, Bristow LJ, Campbell UC, Conn PJ (2002). Behavioral consequences of mGluR5 and NMDA receptor antagonist interaction: implication for schizophrenia. Neuropharmacology 43: 292.

Kozela E, Pilc A, Popik P (2003). Inhibitory effects of MPEP, an mGluR5 antagonist, and memantine, an $N$-methyl-D-aspartate receptor antagonist, on morphine antinociceptive tolerance in mice. Psychopharmacology 165: 245-251.

Krystal JH, Karper LP, Seibyl JP, Freeman GK, Delaney R, Bremner JD et al (1994). Subanesthetic effects of the noncompetitive NMDA antagonist, ketamine, in humans. Psychotomimetic, perceptual, cognitive, and neuroendocrine responses. Arch Gen Psychiat 51: 199-214.

Lahti AC, Weiler MA, Michaelidis T, Parwani A, Tamminga CA (2001). Effects of ketamine in normal and schizophrenic volunteers. Neuropsychopharmacology 25: 455-467.

Leppik IE, Marienau K, Graves NM, Rask CA (1988). MK-801 for epilepsy: a pilot study. Neurology 38: 405.

Luby E, Cohen B, Rosenbaum G, Gottlieb J, Kelley R (1959). Study of a new schizophrenomimetic drug - sernyl. Am Med Ass Arch Neurol Psychiatr 81: 363-369.

Luthi A, Gahwiler BH, Gerber U (1994). Potentiation of a metabotropic glutamatergic response following NMDA receptor activation in rat hippocampus. Pffugers Arch 427: 197-202.

Malhotra AK, Pinals DA, Adler CM, Elman I, Clifton A, Pickar D et al (1997). Ketamine-induced exacerbation of psychotic symptoms and cognitive impairment in neuroleptic-free schizophrenics. Neuropsychopharmacology 17: 141-150.

Manahan-Vaughan D, Braunewell KH (2005). The metabotropic glutamate receptor, mGluR5, is a key determinant of good and bad spatial learning performance and hippocampal synaptic plasticity. Cereb Cortex 15: 1703-1713.

Marino MJ, Conn PJ (2002). Direct and indirect modulation of the $\mathrm{N}$-methyl-D-aspartate receptor. Curr Drug Targets CNS Neurol Disord 1: 1-16.

McAllister KH (1990). Ethological analysis of the effects of MK-801 upon aggressive male mice: similarity to chlordiazepoxide. Pharmacol Biochem Behav 37: 101-106.

Mohn AR, Gainetdinov PR, Caron MG, Koller BH (1999). Mice with reduced NMDA receptor expression display behaviors related to schizophrenia. Cell 98: 427-436.

Morgan CJA, Mofeez A, Brandner B, Bromley L, Curran HV (2004). Acute effects of ketamine on memory system and psychotic symptoms in healthy volunteers. Neuropsychopharmacology 29: 208-218.

Mueser KT, McGurk SR (2004). Schizophrenia. Lancet 363: $2063-$ 2072.

Nagai T, Noda Y, Une T, Furukawa K, Furukawa H, Kan QM et al (2003). Effect of AD-5423 on animal models of schizophrenia: phencyclidine-induced behavioral changes in mice. NeuroReport 14: $269-272$.

Nicholson KL, Jones HE, Balster RL (1998). Evaluation of the reinforcing and discriminative stimulus properties of the lowaffinity $N$-methyl-D-aspartate channel blocker memantine. Behav Pharmacol 9: 231-243.

Ossowska K, Konieczny J, Wolfarth S, Wieronska J, Pilc A (2001). Blockade of the metabotropic glutamate receptor subtype 5 (mGluR5) produces antiparkinsonian-like effects in rats. $J$ Neural Transm Parkinson's Dis Dement Sect 8: 39-71.

Pecknold JC, McClure DJ, Appeltauer L, Wrzesinski L, Allan T (1982). Treatment of anxiety using fenobam (a nonbenzodiazepine) in a double-blind standard (diazepam) placebo-controlled study. J Clin Psychopharmacol 2: 129-133.

Pietraszek M, Gravius A, Schäfer D, Weil T, Trifanova D, Danysz W (2005). mGluR5, but not mGluR1, antagonist modifies MK801 -induced locomotor activity and deficit of prepulse inhibition. Neuropharmacology 49: 73-85.

Pintor A, Pezzola A, Reggio R, Quarta D, Popoli P (2000). The mGlu5 receptor agonist CHPG stimulates striatal glutamate release: possible involvement of A2A receptors. NeuroReport 11: 3611-3614.

Porter RH, Jaeschke G, Spooren W, Ballard TM, Buttelmann B, Kolczewski S et al (2005). Fenobam: a clinically validated nonbenzodiazepine anxiolytic is a potent, selective, and noncompetitive mGlu5 receptor antagonist with inverse agonist activity. J Pharmacol Exp Ther 315: 711-721.

Rabey JM, Nissipeanu P, Korczyn AD (1992). Efficacy of memantine, an NMDA receptor antagonist, in the treatment of Parkinson's disease. J Neurochem 64: 277-282.

Riederer P, Lange KW, Kornhber J, Danielczyk W (1991). Pharmacotoxic psychosis after memantine in Parkinson's disease. Lancet 338: 1022-1023.

Rodriguez-Arias M, Maldonado C, Aguilar MA, Minarro J (2002). Memantine does not block antiaggressive effects of morphine in mice. Behav Pharmacol 13: 249-252.

Rung JP, Carlsson A, Markinhuhta KR, Carlsson ML (2005a). MK801 induced social withdrawal in rats; a model for negative symptoms of schizophrenia. Prog Neuropsychopharmacol Biol Psychiat 29: 827-832.

Rung JP, Carlsson A, Markinhuhta KR, Carlsson ML (2005b). The dopaminergic stabilizers (-)-OSU6162 and ACR16 reverse (+)MK-801-induced social withdrawal in rats. Prog Neuropsychopharmacol Biol Psychiat 29: 833-839.

Sams-Dodd F (1995). Automation of the social interaction test by video-tracking system: behavioural effects of repeated phencyclidine treatment. J Neurosci Methods 59: 157-167.

Sams-Dodd F (1996). Phencyclidine-induced stereotyped behaviour and social isolation in rats: a possible animal model of schizophrenia. Behav Pharmacol 7: 3-23.

Sams-Dodd F (1997). Effects of novel antipsychotic drugs on phencyclidine-induced stereotyped behaviour and social isolation in the rat social isolation test. Behav Pharmacol 8: 196-215.

Sams-Dodd F (1998). Effects of continuous D-amphetamine and phencyclidine administration on social behaviour, stereotyped behaviour, and locomotor activity in rats. Neuropsychopharmacology 19: 18-25.

Sams-Dodd F (1999). Phencyclidine in the social interaction test: an animal model of schizophrenia with face and predictive validity. Rev Neurosci 10: 59-90.

Sams-Dodd F (2004). MK-801 and phencyclidine induced neurotoxicity do not cause enduring behaviours resembling the positive and negative symptoms of schizophrenia in the rat. Basic Clin Pharmacol Toxicol 5: 241-246.

Sams-Dodd F (2006). Strategies to optimize the validity of disease models in the drug discovery process. Drug Discov Today 11: 355-363. 
Sanger DJ, Terry P, Katz JL (1992). Memantine has phencyclidinelike but not cocaine-like discriminative stimulus effects in rats. Behav Pharmacol 3: 265-268.

Silvestre JS, Nadal R, Pallares M, Ferre N (1997). Acute effects of ketamine in the holeboard, the elvated-plus maze, and the social interaction test in Wistar rats. Depress Anxiety 5: 29-33.

Spooren W, Vassout A, Neijt HC, Kuhn R, Gasparini F, Roux S et al (2000). Anxiolytic-like effects of the prototypica metabotropic glutamate receptor 5 antagonist 2-methyl-6(phenylethynyl)pyridine in rodents. J Pharmacol Exp Ther 295: 1267-1275.

Sukhotina IA, Bespalov AY (2000). Effects of the NMDA receptor channel blockers memantine and MRZ 2/579 on morphine withdrawal-facilitated aggression in mice. Psychopharmacology 149: 345-350.

Tatarczynska E, Klodzinska A, Chojnacka-Wojcik E, Palucha A, Gasparini F, Kuhn R et al (2001). Potential anxiolytic- and antidepressant-like effects of MPEP, a potent, selective and systematically active mGlu5 receptor antagonist. Br J Pharmacol 132: $1423-1430$
Thomas LS, Jane DE, Harris JR, Croucher MJ (2000). Metabotropic glutamate autoreceptors of the mGlu5 subtype positively modulate neuronal glutamate release in the rat forebrain in vitro. Neuropharmacology 39: 1554-1566.

Turle-Lorenzo N, Breysse N, Baunez C, Amalric M (2005). Functional interaction between mGlu5 and NMDA receptors in a rat model of Parkinson's disease. Psychopharmacology 179: 117-127.

Varty GB, Grilli M, Forlani A, Fredduzzi S, Grzelak ME, Guthrie $\mathrm{DH}$ et al (2005). The antinociceptive and anxiolytic-like effects of the metabotropic glutamate receptor 5 (mGluR5) antagonists, MPEP and MTEP, and the mGluR1 antagonist, LY456236, in rodents: a comparison of efficacy and side-effect profile. Psychopharmacology 179: 207-217.

Wiersma D, Wanderling J, Dragomirecka E, Ganev K, Harrison G, an der Heiden W et al (2000). Social disability in schizophrenia: its development and prediction over 15 years in incidence cohorts in six European centres. Psychol Med 30: 1155-1167.

Xie Z, Commissaris RL (1992). Anxiolytic-like effects of the noncompetitive NMDA antagonist MK-801. Pharmacol Biochem Behav 43: 471-477. 